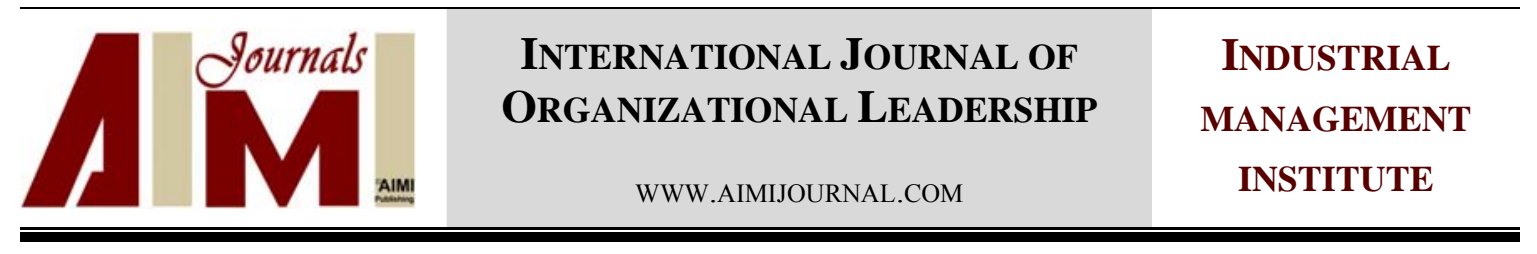

\title{
The effects of financial risks on the relationship between earnings and stock returns
}

\author{
Mehri Akhavi Babi \\ Payame Noor University, Germi Branch, Ardabil, Iran
}

\begin{abstract}
Keywords:

This study was conducted to investigate the effects of financial risks on the relationship between earnings per share and stock returns. The statistical population of the study consisted of the companies accepted by Tehran Stock Exchange. According to the conditions for

Earnings Per Share, Liquidity Risk, Credit Risk, Solvency Risk, Stock Returns sampling, 65 companies were selected during a period of six years from 2008 to 2013 (i.e., 390 fiscal years), and four hypotheses were set forth to achieve the purposes of the study. The first hypothesis tried to assess the relationship between earnings per share and stock returns. The second, third, and fourth hypotheses investigated the significance of the effects of three financial risks, namely liquidity, credit, and solvency risks on the relationship between earnings per share and stock returns. The hypotheses of the study were tested using linear and multiple regressions. The findings of the study indicated that there was a positive and significant relationship between earnings per share and stock returns. In addition, the results proved that the credit and solvency risks had negative and significant effects on the relationship between earnings per share and stock returns, but the effect of liquidity risk on this relationship was not significant.

Correspondence: mehri.akhavi@gmail.com
\end{abstract}

CAIMI Journals

\section{Introduction}

In the modern world of investment, the decision-making process is probably the most important part of investment procedure during which investors need to make the most efficient decisions to maximize their profit and wealth. Therefore, information is the most important factor in decision-making procedure. In securities market, all decisions related to investment are influenced by information sources. The information is collected from some 
sources such as news media, financial analysts, financial statements of companies, and even securities market prices. The theorists of securities market consider accounting and financial reporting as the most important information sources; therefore, one of the objectives of accounting and financial reporting is to provide information for facilitating decision-making process.

Information is also considered as a strategic tool in decision-making, and the quality of decisions depend on the accuracy and appropriateness of the information which is made available during decision-making process. In financial market, information is presented in the form of signs, marks, and different forecasts which are released from inside and outside the companies to be available to the shareholders (Mirnejad, Valipour, \& Alame-Haeri, 2013). To investigate the effect of information on investment, Li and Wu (2014) have studied the relationship between the analysts' forecast dispersion and stock returns with a quantile regression approach. The empirical results of their study showed that dispersion was negatively associated with subsequent stock returns when the latter was in lower quantiles. In contrast, when the stock returns were in high quantiles, dispersion was positively connected with succeeding stock returns. Besides, the relation between dispersion and stock returns was minor when the mid-range return quantiles were concerned.

On the other hand, Purnamasari, Herdjiono, and Setiawan (2012) believe that earnings of companies are one of their crucially important information. Earnings reflect the management performance, estimate the normal profit, and evaluate investment and solvency risk. Earnings which contain information are useful for predicting stock prices. According to efficient market hypothesis, stock prices show immediate reaction to the new information released about them. Finding a relationship between the changes in accounting profit and stock prices is very important because investors believe that the stock prices change according to the ability of the companies to generate profit and, therefore, investors start buying shares when real returns exceed expected returns. The relationship between earnings and stock returns has an important role in the stability of companies (Purnamasari et al., 2012).

Another factor which is of great importance in finance is the concept of risk. This concept is defined based on the fact that all investors try to get the highest return on their investment. In fact, risk and returns are two main principles for investment decisions and the highest return according to the lowest risk is an important criterion for investment. Consequently, the concept of risk has a lot of applications in finance because market participants being faced with any securities ask about its risk level. However, it seems that Iranian investors do not 
pay enough attention to the risk variable alongside the return variable. In other words, although risk and return variables should be considered together and the new share should be regarded as one of the elements of investment portfolio which makes up the whole return, Iranian inventors do not consider risk as an important criterion for investment. Finally, a certain share should be purchased after general analysis of the circumstances (Raei \& Saeidi, 2010).

The logic of the relationship between earnings and returns was first presented by Ball and Brown in 1968 in an article titled as "An empirical evaluation of accounting income numbers" and their null hypothesis stated that accounting income numbers were not useful for stock exchange investors. Therefore, their research hypothesis claimed that these numbers were useful for investors. The findings of their study resulted in the rejection of the null hypothesis and it showed that a general review of the stock prices after the distribution of income reports demonstrated that the information contained in the annual income number was useful and the direction of changes in reported accounting income had positive correlation with the changes in stock prices in comparison to the previous year. They also concluded that the information available in capital market was useful on condition that it evoked investors' reactions to bring up changes in stock prices or in the volume of stock exchanges (Ball \& Brown, 1968).

Shabahang (2003) believes that the dominant paradigm of earnings and returns is a hypothesis based on which the capital market achieves efficiency in comparison to the related information which is available to the public. He also claims that the hypothesis of efficient market refers to the reaction rate of the securities of capital market compared to the distribution of new information. Therefore, the definition of the efficiency of market consists of the fact that the capital market reflects the available information thoroughly and the market prices show immediate reaction to the new information; that is, the new information has immediate effect on the securities price (Shabahang, 2003).

There is a fundamental principle in the field of investment which states that the capital escapes from risk and venture and tends toward earning and return. As a result, the investors who escape from risk prevent their capital from entering to a business situation which is risky and dangerous or the future of their principal and earnings is uncertain. But is there any investment which does not involve risk? Abzari, Samadi, and Teimouri (2008) claim that there is a risk or danger of losing one's principal and interest in every business situation. Some investments have high levels of risk and some others have lower levels of risk. 
Therefore, investors expect adequate earnings and returns according to the level of risk involved in investment. Raei and Saeidi (2010) believe that financial risks have direct influence on the earnings of companies and can even lead to their breakdown.

Therefore, considering the important role of risk in investment, this study was an attempt to investigate the effects of three types of financial risk, namely liquidity, credit, and solvency risks on the relationship between earnings and returns. To get more familiar with the nature of these kinds of risk, each of these risks is touched upon briefly below.

\section{The Literature Review}

Liquidity risk is the risk of lack of cash for the repayment of obligations. Generally, companies are faced with liquidity problems when due to a number of reasons they are not able to sell their products, they cannot receive cash for sale, the costs of production increase extensively, and finally the companies' efficiency decrease. In recent years, the liquidity crisis has occurred in many international companies and a lot of Iranian companies, especially textile industries, are struggling with this problem, and it will recur in many other industries if the economic system of the country continues the way it is working currently. Therefore, this risk of liquidity should be identified correctly because it is the most common risk in our country, and some strategies should be applied to manage the crisis more properly (Raei \& Saeidi, 2010).

The second risk, credit risk, happens in the condition that borrowers are not able or willing to repay their obligations to the lenders in the date of repayment. Lending institutions have special strategies to minimize this risk. For example, they do not give all loans to a specific industry, so that if there is a problem with that industry, the loans are not faced with indefinite fate. Getting acceptable guarantees and collateral are the last resorts to control credit risk (Raei \& Saeidi, 2010).

Finally, solvency risk shows the status of the company according to its ability to pay its liabilities. Therefore, this risk happens when the company is not able to repay its debts and it is calculated through the ratio of total debt to the sum of shareholders' equities. Solvency risk is related to the long-term profitability of the company and to its capacity to meet long-term liabilities. This risk is calculated by the comparison of financial obligations to the returns of bank or company and it is called the ratio of debt to equity. A rising debt-to-equity ratio implies lower stock price and investment return. The reason for this phenomenon is the fact 
that a great amount of the income of banks is transferred to the creditors' account from shareholders' account (Purnamasari et al., 2012).

Because of the importance of the issue of risk, earnings, and returns in investment and their relationships and effects on each other, there have been many investigations in this field. Regarding the relationship between earnings and returns, the research by Chan, Chan, Jegadeesh, and Lakonishok (2006), Allen, Larson, and Richard (2013), Lander, Orphanides, and Douvogiannis (1997), Kothari, Lewellen, and Warner (2006), Liu and Thomas (2000), Lim (2009), Lipe (1990), and Skinner and Sloan (2000) are just a few studies which have looked into the depth of issue.

Allen et al. (2013) examined the relationship between accrual reversals, earnings, and stock returns. Their findings showed that accruals consisted of two distinct underlying processes; one with positive serial correlation and the other with negative serial correlation. They also found that the accrual reversals characterizing the negatively serially correlated processes were mainly good accruals that rightly anticipated fluctuations in working capital. Finally, they proved that accrual estimation error was the least determined component of earnings, while accruals relating to firm growth were less persistent than cash flows.

Chan et al. (2006) studied the earning quality and stock returns. They found that accruals had predictive power for returns and showed earnings manipulations by managers. Lander et al. (1997) worked on earnings forecasts and the predictability of stock returns. They improved an error-correction model based on the theory that stock returns tend to reinstate an equilibrium relationship between the forecasted earnings yield on common stocks and the yield on bonds. Kothari et al. (2006) studied the relationship between stock returns and aggregate earnings surprises and found substantially different patterns from literature on the issue. They found that returns were unrelated to past earnings, suggesting that prices neither underreact nor overreact to aggregate earnings news. They also argued that aggregate returns correlated negatively with concurrent earnings. However, the study by Lim (2009) demonstrated that earnings surprise was significantly correlated with volatility and overnight returns.

On the other hand, there have been a large number of studies on the effect of financial risks on earnings and returns. Soh, Cheng, and Nasir (2009) assessed the effect of interest risk and other financial risks on the earnings response in Thailand bank stock. Cheng and Nasir (2010) investigated seven risk factors effective on earning response coefficients in China commercial banks. The findings of this study demonstrated that the liquidity risk had 
significant effect on the relationship between earnings and returns. Purnamasari et al. (2012) evaluated the effect of financial risks and growth on the relationship between earnings and abnormal stock returns in Indonesia. They studied 22 commercial banks which were in Indonesia stock exchange from 2008 to 2010 . The results of their study proved that there was a significant relationship between unexpected profit and abnormal stock return. Then the effect of growth and three financial risks (i.e., liquidity, credit, and solvency risks) on this relationship was assessed and it was found that growth and solvency risk had negative effect on the relationship between earnings and abnormal stock returns, but liquidity and credit risks had no significant effect on this relationship.

However, the effect of every financial risk on earnings and returns are studied separately, too. Bekaert, Harvey, and Lundblad (2007), Dalgaard (2009), Pastor and Stambaugh (2003), Hendershott and Seasholes (2014), Jun, Marathe, and Shawky (2003), Salehi, Talebnia, and Ghorbani (2011), Loukil, Zayani, and Omri (2010), Cao and Petrasek (2014), Liang and Wei (2012), and Bond and Chang (2013) have investigated the relationship between liquidity and stock returns. Bekaert et al. (2007) found that liquidity measures could significantly predict future returns. Pastor and Stambaugh (2003) demonstrated that expected stock returns were cross-sectionally associated with the sensitivities of returns to fluctuations in aggregate liquidity. Jun et al. (2003) stated that stock returns in emerging countries were positively correlated with aggregate market liquidity as estimated by turnover ratio, trading value, and the turnover-volatility multiple. Salehi et al. (2011) investigated the relationship between liquidity and stock returns of companies listed in Tehran stock exchange. The results of their study indicated that there was a negative correlation between stock returns with its liquidity. Cao and Petrasek (2014) conducted a research on liquidity risk and institutional ownership to assess the effect of liquidity risk on stock returns. They found that the market risk which was calculated by market beta could properly predict abnormal stock return during liquidity crises. In contrast, abnormal stock return during liquidity crises which had strongly negative association with liquidity risk was assessed through the simultaneous movement of stock return with market liquidity. Loukil et al. (2010) examined the effect of liquidity on stock returns in the Tunisian stock market. Their findings presented evidence that there was a significant and positive premium for companies with high price impact and low trading frequency. They also demonstrated that there was a non-linear relation between potential delays of execution and stock returns. These findings had profound consequences on controlling liquidity risk of stock exchange. 
On the other hand, the effect of the second risk factor of this study, credit risk, on stock returns has been studied by Steiger (2010), Kang and Kang (2009), Correa, Lee, Sapriza, and Suarez (2014), and Friewald, Wagner, and Zechner (2014). The results of the study by Steiger (2010) revealed that credit risk and implied volatility had great explanatory power with respect to stock returns. In addition, Correa et al. (2014) observed and examined the joint effect of expected government support to banks and changes in sovereign credit ratings on bank stock returns using data for banks in 37 countries between 1995 and 2011. They argued that sovereign credit rating downgrades had a great negative effect on bank stock returns for those banks that were supposed to receive considerable support from their governments.

Finally, regarding the financial risk of solvency and returns, Nethra and Kushalappa (2015) assessed the impact of financial solvency on stock returns. They proved that the companies with sound financial position could perform better in the stock market than the stocks of financially weak companies.

To conclude, it should be mentioned that although there have been many investigations on the relationship between earnings and returns and the effect of financial risk on earnings or returns, there have been very few studies on the effect of risks factors on the relationship between earnings and returns. In addition, there have been many controversies and limitations in the prior investigations about these issues. Therefore, all these shortcomings made it necessary to conduct a more extensive research on this issue.

\section{Research Hypotheses}

The purpose of this study was to investigate the effects of financial risks on the relationship between earnings per share and stock returns of the companies accepted in Tehran Stock Exchange. Therefore, according to the purpose of the study, the following research hypotheses underpin the study:

$\mathrm{H}_{1}$ : There is a significant relationship between earnings per share and stock returns.

$\mathrm{H}_{2}$ : Liquidity risk has significant effect on the relationship between earnings per share and stock returns,

$\mathrm{H}_{3}$ : Credit risk has significant effect on the relationship between earnings per share and stock returns.

$\mathrm{H}_{4}$ : Solvency risk has significant effect on the relationship between earnings per share and stock returns. 


\section{Method}

The statistical population of the study consisted of all the companies which were accepted in Tehran Stock Exchange during a period of six years from 2008 to 2013, and the statistical sample was composed of the companies which met a series of conditions; the companies possessed all required information during the period of six years; they were accepted in stock exchange before 2008 and their logos were not deleted from stock exchange board; their financial year-end was 31 March of each year; and they were not financial companies (i.e., investment, holding, and intermediation companies). Finally, 65 companies were selected during six years from 2008 to 2013 and, therefore, the data of 390 fiscal years were gathered and analyzed.

This study was a descriptive correlational applied research of survey type which used linear and multiple regressions for testing the hypotheses. The mathematical models of the research for testing the hypotheses 1 to 4 were as following respectively:

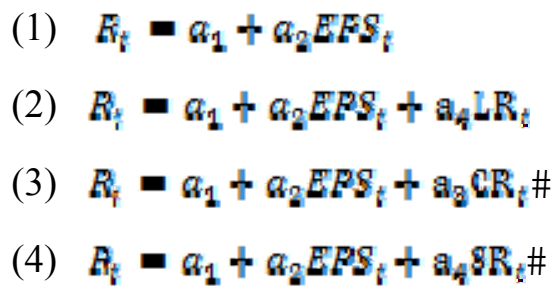

For gathering the data and testing the hypotheses, all variables of the study, namely stock returns, earnings, liquidity risk, credit risk, and solvency risk were defined operationally. Stock return was defined as the changes in wealth or capital due to the investment. These changes can occur because of cash flows such as interests or earnings, or it can happen as the result of negative or positive changes in capital prices (Jones, 2012). In the present study, the following formula, which was adapted from Talebniya and Zare Nikouparvar Yazdi (2010) was used for calculating stock returns:

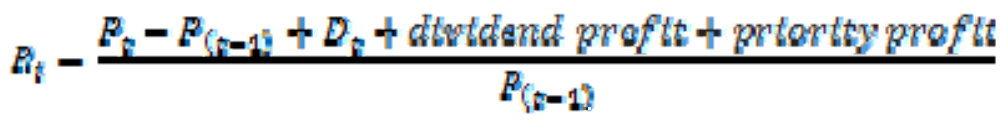

On the other hand, earning per share was one of the common and conventional indicators of performance which was also used for evaluating stock prices and was expressed in Rials. It was calculated through dividing common shareholders' net income by the weighted average 
common shares outstanding. The result of the ratio showed the amount of earnings per share, and higher earnings per share ratio indicated higher company efficiency. Therefore, it was used for the evaluation of shares in a way that the future price of shares was determined according to the market price of the shares (trading price of shares) (Moeinoddin, Naiebzade, Zaree-Mehrjardi, \& Fazel-Yazdi, 2013).

Finally, liquidity risk as one of the independent variables of the study was calculated by the ratio of net debt to total assets, credit risk was assessed by the ratio of doubtful debts to current debts, and solvency risk was evaluated by the ratio of total debts to the sum of shareholders' equity.

In the present study, library research was used for data gathering. The data required for reviewing the literature were collected from books, journals, articles, and university theses. In addition, the statistical information and data for testing the hypotheses were collected from the websites of Tehran Stock Exchange Corporation (e.g., SEO, CODAL, and RDIS) and the software of Tehran Stock Exchange Corporation (e.g., Tadbir Pardaz and Rahavard Novin). The research data were obtained from analyzing audited financial statements and the board of directors' report on the financial year-end of companies recorded in the data bank of Tehran Stock Exchange Corporation. The variables of the study were also calculated using Microsoft Excel. However, the final analysis of data was done using SPSS statistical software.

\section{Results}

The data were analyzed at two levels of statistical analysis including descriptive and inferential analysis. At descriptive level, the distribution of the companies selected in six years was as presented in Table 1 . As it is shown in Table 1 the number of fiscal years was 390 years (i.e., 65 companies $\times 6$ years $=390$ fiscal years).

Table 1

Distribution of Samples According to Years

\begin{tabular}{cc}
\hline Year & Sample \\
\hline 2008 & 65 \\
2009 & 65 \\
2010 & 65 \\
2011 & 65 \\
2012 & 65 \\
2013 & 65 \\
All & 390 \\
\hline
\end{tabular}

At descriptive level, the data were also analyzed based on their central tendency and dispersion. The mean and standard deviation of the data about research variables are presented in Table 2 . 
Table 2

Descriptive Statistics of the Data for Variables

\begin{tabular}{ccccc}
\hline Variable & Max & Min & $M$ & $S D$ \\
\hline Returns & 0.77 & -1.00 & 0.19 & 33 \\
Earnings Per Share & 6572 & -1737 & 818.77 & 901.92 \\
Liquidity Risk & 2.36 & 0.01 & 0.57 & 0.24 \\
Credit Risk & 0.92 & 0.0004 & 0.081 & 0.16 \\
Solvency Risk & 26.23 & -45.11 & 1.59 & 4.26 \\
\hline
\end{tabular}

However, at inferential level, the normality of the data was tested using One-Sample Kolmogorov-Smirnov test (K-S test). Table 3 depicts the results of normality test.

Table 3

Normality Test of Data for Variables

\begin{tabular}{cccc}
\hline Variable & Number & K-S & Sig. \\
\hline Returns & 390 & 0.958 & 0.370 \\
Earnings per Share & 390 & 3.112 & 0.000 \\
Liquidity Risk & 390 & 2.063 & 0.000 \\
Credit Risk & 390 & 6.705 & 0.000 \\
Solvency Risk & 390 & 6.851 & 0.000 \\
\hline
\end{tabular}

K-S = One-Sample Kolmogorov-Smirnov Test; Sig. $=$ Calculated Statistical Significance

As it is presented in Table 3, the normality test of One-Sample K-S test showed that the calculated statistical significance for dependent variable (i.e., stock return) was greater than the significance level $(\alpha=0.05)$, and the distribution of the data for this variable were normal. However, because of the fact that the calculated statistical significances for independent variables of earnings per share, liquidity risk, credit risk, and solvency risk were smaller than the significance level of 0.05 per cent, the distribution of the data related to these variables were non-normal. As a result, considering the normality of the data for stock returns (dependent variable), linear regression could be used for testing the first hypothesis.

The first hypothesis stated that there was a significant relationship between earnings per share and stock returns. The linear regression presented above as the first model (i.e., $\left.R_{t}=a_{1}+a_{2} E E S_{\hbar}\right)$ was used for testing this hypothesis. The findings related to the first hypothesis are illustrated in Table 4.

Table 4

Linear Regression Analysis Predicting Stock Returns from Earnings per Share

\begin{tabular}{|c|c|c|c|c|c|c|c|c|}
\hline Variable & $d$ & $F$ & Sig. & $B$ & SE & Beta & $t$ & $p$ \\
\hline Model 1 & 1.951 & 19.4 & 0.000 & & & & & \\
\hline Constant & & & & 0.125 & 0.022 & & 5.71 & 0.000 \\
\hline $\begin{array}{c}\text { Earnings per } \\
\text { Share }\end{array}$ & & & & 0.00008 & 0.000018 & 0.218 & 4.41 & 0.000 \\
\hline
\end{tabular}


According to Table 4, since Durbin-Watson statistic of 1.951 was greater than critical value of 1.5 (i.e., $d>1.5$ ), there was no statistical evidence that the error terms were negatively auto-correlated. In addition, the $F$ calculated from the data with a value of 19.4 and statistical significance of 0.000 (i.e., $\alpha<0.05$ ) showed that model 1 provided a significantly better fit for testing the hypothesis. The calculated beta coefficient (i.e., the standardized coefficient for independent variable of earnings per share) had a value of 0.218. This value of beta demonstrated that 0.218 standard deviations stock returns would change, per standard deviation change in independent variable of earnings per share. Considering the fact that the calculated beta coefficient was a positive value, there was, therefore, a direct and positive relationship between earnings per share and stock returns. In $t$-test, the calculated $p$ value for independent variable of earnings per share was below the threshold chosen for statistical significance (i.e., 0.05 level), and the null hypothesis that there was no significant relationship between variables was rejected in favor of the alternative hypothesis. Therefore, based on the results of the analysis of the first hypothesis, it could be claimed that there was a significant relationship between earnings per share and stock returns.

The second hypothesis tried to test if liquidity risk had any significant effect on the relationship between earnings per share and stock returns. Multiple regression shown in equation 2 (i.e., $R_{t}=a_{1}+a_{2} E E S_{i}+a_{4} L R_{t}$ ) was used to test this hypothesis. Table 5 illustrates the results of testing the second hypothesis.

Table 5

Multiple Regression Analysis Predicting Stock Returns and Earnings per Share from Liquidity Risk

\begin{tabular}{|c|c|c|c|c|c|c|c|c|}
\hline Variable & $d$ & $F$ & Sig. & $B$ & $S E$ & Beta & $t$ & $p$ \\
\hline Model 2 & 1.936 & 10.97 & 0.000 & & & & & \\
\hline Constant & & & & 0.171 & 0.046 & & 4.65 & 0.00 \\
\hline $\begin{array}{l}\text { Earnings per } \\
\text { Share }\end{array}$ & & & & 0.000079 & 0.000018 & 0.217 & 4.32 & 0.00 \\
\hline Liquidity Risk & & & & -0.080 & 0.051 & -0.078 & -1.46 & 0.116 \\
\hline
\end{tabular}

As it is shown in Table 5, the Durbin-Watson statistic of 1.936 which was greater than critical value of 1.5 (i.e., $d>1.5$ ) demonstrated that the error terms were not negatively autocorrelated. In addition, the calculated value of $F$ which showed a number of 10.97 with statistical significance of 0.000 (i.e., $\alpha<0.05$ ) proved that the regression model used for the second hypothesis provided a significantly better fit for testing the hypothesis. The calculated beta coefficient for independent variable of earnings per share had a value of 0.217 with 
statistical significance of 0.000 (i.e., $\alpha<0.05$ ). This value of beta indicated that there was a positive and significant relationship between earnings per share and stock returns. However, the standardized beta coefficient for independent variable of liquidity risk had a value of 0.078 with statistical significance of 0.116 (i.e., $p>0.05$ ). Therefore, these findings demonstrated that liquidity risk had negative effect on the relationship between earnings per share and stock returns, and considering the level of statistical significance for liquidity risk which was greater than 0.05 , the effect of liquidity risk on the relationship between earnings per share and stock returns was not statistically significant. These results were consistent with the findings of some other researchers such as Soh et al. (2009) and Purnamasari et al. (2012), and they were inconsistent with the findings of Cheng and Nasir (2010) which demonstrated the significant effect of liquidity risk on the relationship between earnings per share and stock returns.

The third research hypothesis tried to test the effect of credit risk on the relationship between earnings per share and stock returns. For testing this hypothesis, Multiple regression shown in equation 3 (i.e., $E_{t}=a_{t}+a_{2} E P S_{t}+a_{2} C R_{t}$ ) was of help. The results for the analysis of the third hypothesis are presented in Table 6.

Table 6 Multiple Regression Analysis Predicting Stock Returns and Earnings per Share from Credit Risk

\begin{tabular}{ccccccccc}
\hline Variable & $d$ & $F$ & Sig. & $B$ & SE & Beta & $t$ & $p$ \\
\hline Model 3 & 1.923 & 12.074 & 0.000 & & & & & \\
Constant & & & & 0.145 & 0.024 & & 6.119 & 0.000 \\
Earnings per share & & & & 0.000077 & 0.000018 & 0.213 & 4.303 & 0.000 \\
Credit risk & & & & -0.221 & 0.104 & -0.106 & -2.137 & 0.033 \\
\hline
\end{tabular}

Note. $d=$ Durbin-Watson statistic; $F=F$-test statistic; Sig. $=$ calculated statistical significance. $B=$ standardized regression coefficient; $S E=$ standard error; Beta $=$ standardized coefficient

The Durbin-Watson statistic of 1.923, illustrated in Table 6, was greater than critical value of 1.5 (i.e., $d>1.5$ ). Therefore, there was no statistical evidence that the error terms were negatively auto-correlated. In addition, the calculated $F$ value of 12.074 with statistical significance of 0.000 (i.e., $\alpha<0.05$ ) demonstrated that the regression model used for the third hypothesis provided a significantly better fit for hypothesis testing. The standardized beta coefficient for independent variable of earnings per share was 0.213 with statistical significance of 0.000 (i.e., $\alpha<0.05$ ). This value of beta clearly proved that there was a positive and significant relationship between earnings per share and stock returns. On the other hand, the calculated standardized beta coefficient for independent variable of credit risk was -0.106 with statistical significance of 0.033 (i.e., $p>0.05$ ). These results demonstrated 
that credit risk had negative effect on the relationship between earnings per share and stock returns. In addition, regarding the statistical significance for credit risk, the level of statistical significance with a value smaller than 0.05 proved that this effect was statistically significant. These findings were consistent with that of Cheng and Nasir (2010) which had demonstrated the significant effect of credit risk on earnings. They were, however, inconsistent with the findings of Soh et al. (2009) and Purnamasari et al. (2012).

The fourth and last hypothesis assessed the effect of solvency risk on the relationship between earnings per share and stock returns. The multiple regression presented in model 4 above (i.e., $E_{t}=a_{1}+a_{2} E P S_{t}+a_{i} g R_{t}$ ) was used for testing this hypothesis. The results of testing this hypothesis are illustrated in Table 7.

Table 7

Multiple Regression Analysis Predicting Stock Returns and Earnings per Share from Solvency Risk

\begin{tabular}{|c|c|c|c|c|c|c|c|c|}
\hline Variable & $d$ & $F$ & Sig. & $B$ & $S E$ & Beta & $t$ & $p$ \\
\hline Model 4 & 1.933 & 13.964 & 0.000 & & & & & \\
\hline Constant & & & & 0.141 & 0.022 & & 6.285 & 0.00 \\
\hline Earnings per Share & & & & 0.000078 & 0.000018 & 0.217 & 4.413 & 0.00 \\
\hline Solvency risk & & & & -0.083 & 0.003 & -0.140 & -2.86 & 0.004 \\
\hline
\end{tabular}

According to Table 7, the Durbin-Watson statistic of 1.933 was greater than critical value of 1.5 (i.e., $d>1.5$ ). Therefore, the error terms were not negatively auto-correlated. The calculated $F$ statistic also showed a value of 13.964 with statistical significance of 0.000 (i.e., $\alpha<0.05$ ). These values proved that the regression model used for the fourth hypothesis provided a significantly better fit for testing the hypothesis. The standardized beta coefficient for the variable of earnings per share had a value of 0.217 with statistical significance of 0.000 (i.e., $\alpha<0.05$ ). This value of beta coefficient demonstrated that there was a positive and significant relationship between earnings per share and stock returns. However, the standardized beta coefficient for independent variable of solvency risk was -0.140 with statistical significance of 0.004 (i.e., $p<0.05$ ). As a result, solvency risk had negative effect on the relationship between earnings per share and stock returns. Evaluating the level of statistical significance also proved that solvency risk with a statistical significance smaller than 0.05 had significant effect on the relationship between earnings per share and stock returns. It should be mentioned that these results were consistent with the findings of Soh et al. (2009) and Purnamasari et al. (2012), and inconsistent with that of Cheng and Nasir (2010). 


\section{Discussion and Conclusion}

This study was conducted for the purpose of evaluating the effects of financial risks on the relationship between earnings per share and stock returns. The results of the study showed that there was a positive and significant relationship between earnings per share and stock returns. In addition, it was demonstrated that credit and solvency risks had negative and significant effects on the relationship between earnings and returns. Therefore, according to these findings, it is argued that the companies accepted in stock exchange pay special attention to these risk factors during initial evaluations for buying a share. However, liquidity risk had no significant effect on the relationship between earnings per share and stock returns.

Although this study tried to be more detailed and extensive than the prior studies, it suffered from a number of limitations. It was restricted to the investigation of the effects of financial risks on the relationship between earnings per share and stock returns. However, other factors could also have effects on this relationship. Therefore, they are strongly recommended to be studied in future research. Future researchers are suggested to study the effects of market risk, commercial risk, growth, capital structure, and so forth on the relationship between earnings and returns. In addition, this study investigated the companies accepted in stock exchanges. Future studies can look into banks, investment institutions and companies, and other organizations. In other words, applying the research design to other companies and profession is recommendation for future research, and to increase the generalizability of the present study, more data collection from various locations is needed.

\section{References}

Abzari, M., Samadi, S., \& Teimouri, H. (2008). An investigation of the factors effective on the investment in stock exchange. Ravand Journal, 54, 123-152.

Allen, E., Larson, C., \& Richard, G., S. (2013). Accrual reversals, earnings and stock returns. Journal of Accounting \& Economics, 56(1), 113-129.

Ball, R., \& Brown, P. (1968). An empirical evaluation of accounting income numbers. Journal of Accounting Research, 6(2), 159-178.

Bekaert, G., Harvey, C. R., \& Lundblad, C. (2007). Liquidity and expected returns: Lessons from emerging markets. Review of Financial Studies, 20(6), 1783-1831.

Bond, S. A., \& Chang, Q. (2013, February). Liquidity Risk and Stock Returns: A Return Decomposition Approach. Paper presented at Annual Meeting of Midwest Finance Association, Chicago, IL.

Chan, K., Chan, L. K. C., Jegadeesh, N., \& Lakonishok, J. (2006). Earnings quality and stock returns. Journal of Business, 79(3), 1041- 1082.

Cheng A., \& Nasir, A. (2010). Earning response coefficients and the financial risks of China commercial banks. International Review of Business Research Papers, 6(3), 178-188.

Cao, C., \& Petrasek, L. (2014). Liquidity risk and institutional ownership. Journal of Financial Markets, 17, 1-52.

Correa, R., Lee, K. H., Sapriza, H., \& Suarez, G. A. (2014). Sovereign credit risk, banks' government support, and bank stock returns around the world. Journal of Money, Credit \& Banking, 46(1), 93-121.

Dalgaard, R. (2009). Liquidity and stock returns: Evidence from Denmark (Unpublished master's thesis). Copenhagen Business School, Denmark.

Friewald, N., Wagner, C., \& Zechner, J. (2014). The cross-section of credit risk premia and equity returns. The Journal of Finance, 69(6), 2419-2469. 
Hendershott, T., \& Seasholes, M. S. (2014). Liquidity provision and stock return predictability. Journal of Banking and Finance, 45(1), 140-151.

Jones, C. P. (2012). Investments: Analysis and management (12 ${ }^{\text {th }}$ ed.). Hoboken, NJ: John Wiley \& Sons.

Jun, S. G., Marathe, A., \& Shawky, H. A. (2003). Liquidity and stock returns in emerging equity markets. Emerging Markets Review, 4(1), 1-24.

Kang, C., \& Kang, H. (2009). The effect of credit risk on stock returns. Journal of Economic Research, 14(2), 49-67.

Kothari, S. P., Lewellen, J., \& Warner, J. B. (2006). Stock returns, aggregate earnings surprises, and behavioral finance. Journal of Financial Economics, 79(3), 537-568.

Lander, J., Orphanides, A., \& Douvogiannis, M. (1997). Earnings forecasts and the predictability of stock returns: Evidence from trading the S\&P. Journal of Portfolio Management, 23(4), 24-35.

Li, M. Y, \& Wu, J. S. (2014). Analysts' forecast dispersion and stock returns: A quantile regression approach. Journal of Behavioral Finance, 15(3), 175-183.

Liang, S. X., \&Wei, J. K. C. (2012). Liquidity risk and stock returns around the world. Journal of Banking and Finance, 36(12), 3247-3288.

Lim, S. (2009). Assessing the effects of earnings surprise on returns and volatility with high frequency data. Durham, NC: Duke University.

Lipe, R. (1990). The relation between stock returns and accounting earnings given alternative information. The Accounting Review, 65(1), 49-71.

Liu, J., \& Thomas, J. (2000). Stock returns and accounting earnings. Journal of Accounting Research, 38, 71-101.

Loukil , N., Zayani, M. B., \& Omri, A. (2010) Impact of liquidity on stock returns: An empirical investigation of the Tunisian stock market. Macroeconomics \& Finance in Emerging Market Economies, 3(2), 261-283.

Moeinoddin, M., Naiebzade, S., Zare Mehrjardi, R., \& Fazel Yazdi, A. (2013). The study of the beneficially contrarian investment strategy to gain the return and analyze sensitivity of financial indicators by using Tukey test in Tehran stock exchange. Financial Knowledge of Securities Analysis, 6(18), 49-69.

Mirnejad, J., Valipour, H., \& Alame-Haeri, F. (2013). Effects of the reaction of abnormal returns to unexpected earnings with respect to earnings and motives for earnings management. Paper presented at the First National Conference of Accounting and Management, Shiraz, Iran.

Nethra, N., \& Kushalappa, S. (2015). Impact of financial solvency on stock returns. International Journal of Trade \& Global Business Perspectives, 4(1), 1610-1614.

Pastor, L., \& Stambaugh, R. F. (2003). Liquidity risk and expected stock returns. The Journal of Political Economy, 111(3), 642-685.

Purnamasari, K., Herdjiono, I., \& Setiawan, E. (2012). Financial risks, growth, earnings and stock returns relationship: The case of Indonesia. International Review of Business Research Papers, 8(7), 79-93.

Raei, R., \& Saeidi, A. (2010). The principles of financial engineering and risk management ( $5^{\text {th }}$ ed.). Tehran, Iran: SAMT.

Salehi, M., Talebnia, G., \& Ghorbani, B. (2011). A Study of the relationship between liquidity and stock returns of companies listed in Tehran stock exchange. World Applied Sciences Journal, 12(9), 1403-1408.

Shabahang, R. (2003). Accounting theory. Tehran, Iran: The Research Center for Accounting and Audit, Audit Organization.

Skinner, D. J., \& Sloan, R. G. (2000). Earnings surprises, growth expectations, and stock eeturns or don't let an earnings torpedo sink your portfolio. Review of Accounting Studies, 7(2/3), 289-312.

Soh, W. N., Cheng, A., \& Nassir, A. (2009). The effect of financial risk on the earnings response in Thailand bank stock. International Research Journal of Finance and Economics, 31, 55-65.

Steiger, F. (2010). The impact of credit risk and implied volatility on stock returns. Cambridge, MA: Harvard University.

Talebniya, G., \& Zare Nikouparvar Yazdi, M. (2010). The effects of financial variables on the volume of exchanges of the companies in Tehran stock exchange. Financial Research, 12(29), 79-98 